Valaskova, K., Androniceanu, A-M., Zvarikova, K., \& Olah, J. (2021). Bonds Between Earnings

Management and Corporate Financial Stability in the Context of the Competitive Ability of Enterprises.

Journal of Competitiveness, 13(4), 167-184. https://doi.org/10.7441/joc.2021.04.10

\title{
Bonds Between Earnings Management and Corporate Financial Stability in the Context of the Competitive Ability of Enterprises
}

\section{- Katarina Valaskova, Ane-Mari Androniceanu, Katarina Zvarikova, Judit Olab}

\begin{abstract}
The financial health of enterprises and their continued profitability and competitiveness in the market are influenced considerably by the level of earnings achieved. Enterprises are forced to report the best possible results to demonstrate financial strength and competitiveness and to provide a good accounting for investors and creditors. Thus, the main objective of the study is to investigate whether there is any mutual dependence between corporate financial stability and earnings management. To measure these categories, Altman's Z score was used to determine the financial health of enterprises, and the Beneish M-score and modified Jones model were applied to detect earnings manipulation. Using the chi-square test, the results revealed a statistically significant dependence between financial distress and earnings manipulation. Then, a multivariate statistical technique of correspondence analysis was applied to the categorical data to find categories of factors that are mutually correspondent. Based on a dataset of 11,105 enterprises operating in the Visegrad countries, the results found that enterprises that are threatened by bankruptcy or located in the gray zone tend to manipulate their earnings to maintain credibility, creditworthiness, and competitiveness. Because the financial health of an enterprise provides a potential incentive for earnings manipulation, state authorities, regulators, and policy-makers may benefit from the findings of the study.
\end{abstract}

Keywords: financial distress, earnings management, competitive behavior, Z score, M-score, modified Jones model JEL Classification: C12, G32, G40

Received: March, 2021

1st Revision: November, 2021

Accepted: November, 2021

\section{INTRODUCTION}

An analysis of corporate financial health plays a crucial role in the lifecycle of an enterprise. One important indicator of the enterprise's current condition is its financial status. Due to dynamic market changes and constant competitive pressure, companies are compelled to adapt to current market conditions. Based on the financial health analysis, corporate managers have the ability 
to make decisions that may affect the future direction of the company, for example, deciding on future directions and trends for the company in order to attract investors and improve competitiveness. As stated by Gavurova et al. (2020), the competitiveness of companies and economies is a key economic indicator. Every rational entrepreneur starts a business with the idea of prosperity. However, according to defined lifecycles, a company eventually reaches a crisis point and is forced to make changes to survive in the business environment. One of these changes is the use of earnings management practices. An increase in earnings represents an increase in the value of the company, and a decrease in earnings signals a decrease in value. Thus, the management of a company generally has a fundamental interest in earnings management (Siekelova et al., 2020; Lyons \& Lazaroiu, 2020). For this reason, it is important for executives to understand the implications of their accounting decisions and to be able to make the best decisions for the company (Belas et al., 2020a; Savova, 2021). The importance of financial stability and competitiveness compel enterprises to manage their financial outcomes. Various studies map the link between earnings management and competitiveness. To obtain a higher degree of earnings management, enterprises may want to demonstrate their positive market value by reporting satisfactory earnings (Chang et al., 2019; Markarian \& Santalo, 2014). Kordestani \& Mohammdi (2016) show that one of the most relevant determinants of earnings management is market competition. Managers are compelled to manipulate earnings, reduce financial pressures and capital costs or lower product prices to compete intensively and successfully. Moreover, Laksmana \& Yang (2015) confirmed that enterprises with insufficient market competitiveness were more inclined to practice earnings management. El Diri (2020) also contributed to this body of research, proving the significant effect of market competitiveness on earnings management.

The main purpose of this paper is to demonstrate the mutual dependence between financial stability and earnings management behavior in the context of corporate competitive ability. To do so, the study relied on a sample of 11,105 enterprises from the Visegrad countries, applying Altman's model to assess the financial status of the enterprises and applying the Beneish model and the modified Jones model to detect earnings manipulation. The research assumes that an enterprise on the verge of bankruptcy and in financial distress is incentivized to engage in the manipulation of earnings to improve its market position and portray its financial state in the most positive way. To meet the aim of the research, a study was conducted to determine whether: (1) there is any statistically significant dependence between the financial health of enterprises and the manipulation of their earnings; and (2) the factors influencing financial health and earnings manipulation are mutually correspondent. To investigate the relationship between financial health and earnings manipulation, the Altman model was applied to each enterprise to assess its financial situation, and both the Beneish model and the Jones modified model were used to determine whether earnings had been manipulated. As stated by MacCarthy (2017), the Altman $\mathrm{Z}$ score model should be used with financial reports that have not been manipulated, while the Beneish M-score determines whether the financial reports have been manipulated in the first instance. Although several studies have described the role of financial health in earnings manipulation (Al-Delawi \& Ramo, 2020), this issue has not yet been discussed within Central European countries, which makes the research unique in this context. The investigation is pioneering not only in terms of its spatial orientation but also the size of its dataset - analyzing 11,105 enterprises from the Visegrad countries during a 4-year period. 
The paper is divided into the following sections. The theoretical background section presents the most recent and significant studies analyzing the importance of an enterprise's financial stability on earnings management measured by Altman's Z score. The research objective, methodology, and data sections provide detailed information on the dataset of the Visegrad enterprises and the methodological steps that were followed to analyze the dataset. The Results and Discussion section summarizes the primary research findings and compares them with other studies conducted worldwide. Finally, the conclusion section describes the limitations of the study, its practical implications, and possible directions for future research on earnings management practice.

\section{THEORETICAL BACKGROUND}

The inability to generate sufficient financial inflows results in an inability to meet short-term obligations, which is one of the most frequently cited reasons for bankruptcy (Deakin, 1972; Gilson, 1989); thus, an evaluation of the effectiveness of corporate finance plays a crucial role in financial stability (Durana et al., 2020b; Filova \& Folvarcna, 2020). In a study of 55 bankrupts and 198 solvent companies on the quality of earnings, Ahmadpour \& Shahsavari (2016) show that both bankrupt and solvent enterprises tend to use earnings management. Opportunistic earnings management is typical of bankrupt enterprises, while efficient earnings management is typical of solvent enterprises. Cho et al. (2012) claim that although Altman's Z score has been used to predict bankruptcy for several years, it does not consider the role of earnings management practices. Cho et al. (2012) modified the original Z score to reveal that it was understated for the income-decreasing earnings management sample. The relationship between the financial instability of an enterprise and earnings manipulation was also observed by Argawal \& Chatterjee (2015), who analyzed 150 Indian enterprises in a 6-year period following the global financial crisis. Their study, based on the application of the Jones-modified model, Altman's model, and distance-to-default measure, shows that less distressed enterprises are more engaged in manipulating their earnings. These findings may help lenders and investors avoid financial risk (Khan et al., 2019), as they conclude that the first financial report may conceal the real credibility of corporate financial reports. Pustylnick (2015) used a DuPont analysis as a measure to detect earnings manipulation and the Altman Z score to calculate liquidity, combining these two methods to investigate potential manipulation. The application of discriminant analysis proved that the sample of financially stable enterprises is much better than the arbitrary sample produced when searching for earnings manipulation. Chen et al. (2010) used discretionary accruals to analyze the earnings management behavior of financially distressed Chinese enterprises. They revealed that enterprises that operate in less-regulated industries tend to engage in more earnings manipulation. Industry regulation is highly recommended to control earnings management behavior (Belas et al., 2020b; Datta et al., 2013). Similar research was conducted in Taiwan (Chou et al., 2012), analyzing the relationship between corporate information disclosure and financial distress. Furthermore, Beneish et al. (2012) insist that analyzing the earnings management behavior of distressed enterprises may increase the power of realized tests. Aviantara (2021) found that the occurrence of fraud is lower during periods of financial health, applying five of the most important research models - Altman Z score, Springate S-score, 
Grover G-score, Beneish M-score, and Dechow F-score - to study the relationship between financial distress and fraudulent financial statements over a 12 -year period. The issuance of new debt provides a major impetus for bankrupt enterprises to engage in earnings manipulation, as confirmed in the research of Kramolis \& Dobes (2020) or Xu et al. (2021). Building upon this research, Hakami et al. (2020) showed that the Dechow-F score has a much higher success rate of detecting earnings management than the Beneish M or Altman Z models in a study of 365 companies in the period from 2015 to 2017 . However, they also assert that the Beneish model is the most appropriate tool to detect financial fraud in companies associated with local auditing firms. Razali et al. (2014) focused their investigation on 227 publicly listed Malaysian enterprises to measure the probability of fraudulent financial reporting using both the Beneish M-score and Altman's Z score models. Their research shows that effective corporate governance may reduce the probability of fraudulent reporting and moderate the relationship between political influences and real earnings management (Sadiq et al., 2020). This finding is also supported by the research of Kjærland et al. (2020) and Khuong et al. (2020). Malik et al. (2019) employed the Altman model to assess financial distress in Pakistani banks. Using nondiscretionary (NDA) and discretionary accruals (DA) in the logistic approach, they concluded that banks use accruals to manage financial distress, which is an effective insight for regulators, auditors, and investors. Another Pakistani study reveals that there is a positive relationship between earnings management and financial distress; however, this relationship is negatively influenced by ownership structure (Khalid et al., 2020). Ownership may play a role in earnings management behavior, as found by Jacoby et al. (2019), who explored the effects of political affiliation and regional development on the relationship between financial distress and earnings management. Their results are consistent with other relevant studies and suggest that financially distressed enterprises engage more in reporting small positive earnings than financially healthy ones. NDA and DA were also applied by Tbalvandani \& Nashtei (2017), who show that accrual quality and portfolio rank have a statistically significant relationship with future earnings in healthy enterprises, while cash flow does not play a role; in bankrupt enterprises, these factors were insignificant. The study by Hoang \& Joseph (2019) confirms that earnings levels depend on the application of accounting regimes and standards. Lin et al. (2016) included the variable of real earnings management in the $Z$ score model, achieving a greater prediction accuracy rate. This improved accounting-based credit scoring model improved the explanatory power of $\mathrm{Z}$ score factors for the default and survival of an enterprise. Moreover, Campa et al. (2015) found that real earnings management practices are preferred over accrual-based earnings management when managers face or are threatened with bankruptcy. But Li et al. (2020) reached a different conclusion, finding that enterprises that are financially distressed use more accrual earnings management and less real earnings management. However, it is evident that an unfavorable financial situation influences the choice of the earnings manipulation method. Habib et al. (2013) confirm that managers of distressed enterprises tend to practice more income-decreasing earnings management practices than their financially healthy counterparts. A prior experience with financial distress provides an incentive for managers to manipulate earnings in both directions (depending on financial difficulties). A similar study was also conducted by Susanto et al. (2019), who investigated the influence of director size, independence, and managerial ownership on earnings management. In contrast, the study of Sayidah et al. (2020) found that earnings management performed by 
management within specific limits does not affect the financial health of an enterprise. The statistical relationship between the $\mathrm{M}$-score and the $\mathrm{Z}$ score was also the subject of investigation in other studies, e.g., Pustylnick (2017), Balasubramnian et al. (2019), Gottardo \& Moisello (2019), Grofcikova (2020) or Chen et al. (2020).

\section{RESEARCH OBJECTIVE, METHODOLOGY AND DATA}

The main aim of this paper is to demonstrate, verify, and visualize the mutual dependence between corporate financial health and earnings management and reveal potential associations between the categories of the analyzed parameters. To this end, two hypotheses were tested:

1. There is a statistically significant dependence between an enterprise's financial health and the manipulation of earnings.

2. There are categories of factors (financial health, manipulation of earnings) that are mutually correspondent.

The Amadeus database from Bureau van Dijk was used as the dataset of enterprises appropriate for this research. Purposive sampling was applied to ensure that the selection of enterprises was not based only on the size or volume of turnover. Only those enterprises whose total assets are at least 3 million euros, sales are at least 2 million euros, and net income exceeds 100,000 euros are included in the dataset. The application of these criteria produced 1,300 Slovak, 6,352 Polish, 3,679 Czech and 2,423 Hungarian enterprises. The dataset, however, does not offer detailed information for all enterprises, and some of the enterprises were excluded along with other outlying values. The final sample contains information on the 1,240 Slovak, 3,620 Czech, 4,189 Polish, and 2,056 Hungarian enterprises, which are further analyzed during a 4-year period (2016-2019).

The research was conducted according to the following methodological steps:

1. The Altman model was applied to each enterprise and for each year to calculate the $Z$ score and thus the financial situation of each enterprise. The primary aim of the model was to distinguish companies that go bankrupt from those which have a low probability of bankruptcy (Altman, 1968). The model is based on global indices - indices of the overall evaluation, (Equation 1):

$Z$-score $=1.2 \cdot X_{1}+1.4 \cdot X_{2}+3.3 \cdot X_{3}+0.6 \cdot X_{4}+0.998 \cdot X_{5}$

where

$\mathrm{X}_{1}=$ (working capital)/(total assets)

$\mathrm{X}_{2}=$ (retained earnings)/(total assets)

$\mathrm{X}_{3}=$ (earnings before interest and taxes)/(total assets)

$\mathrm{X}_{4}=$ (maret value of equity)/(book value of total liabilities)

$\mathrm{X}_{5}=$ sales/(total assets)

A calculated $\mathrm{Z}$ score determines the financial status of the enterprise. If the $\mathrm{Z}$ score is less than 1.8 , the enterprise is in financial distress; if the score is higher than 3 , it is in the safe zone, 
meaning it is unlikely to file for bankruptcy. $\mathrm{Z}$ scores between 1.8 and 3 indicate a gray zone where an enterprise lacks an unambiguous trend of future development.

2. The Beneish model was employed to calculate the probability of earnings manipulation. Therefore, one of its limitations is that it does not have the ability to detect fraud with complete accuracy. Beneish found that the model could correctly identify up to $76 \%$ of manipulators. Given this percentage of success, the model's calculations are considered reliable information (Beneish, 1999). The Beneish M-score is calculated as (Equation 2):

$M$-score $=-4.84+0.92 \cdot D S R I+0.528 \cdot G M I+0.404 \cdot A Q I+0.892 \cdot S G I+0.115 \cdot D E P I-$

$0.172 \cdot S G A I+4.679 \cdot T A T A-0.327 \cdot L V G I$

where

$$
\begin{aligned}
& D S R I=\frac{\text { net receivables }}{t} / \frac{\text { net receivables }}{\text { sales }_{t}} \\
& G M I=\frac{\left(\text { sales }_{t-1}-\operatorname{COGS}_{t-1}\right)}{\text { sales }_{t-1}} / \frac{\left(\text { sales }_{t}-\text { COGS }_{t}\right)}{\text { sales }_{t}}
\end{aligned}
$$

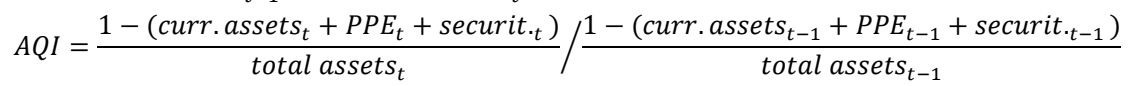

$$
\begin{aligned}
& S G I=\text { sales }_{t} / \text { sales }_{t-1} \\
& D E P I=\frac{\text { depreciation }_{t-1}}{\left(P P E_{t-1}+\text { depreciation }_{t-1}\right)} / \frac{\text { depreciation }_{t}}{\left(P P E_{t}+\text { depreciation }_{t}\right)} \\
& S G A I=\frac{S G \& A \text { expenses }_{t}}{\text { sales }_{t}} / \frac{S G \& A \text { expenses }_{t-1}}{\text { sales }_{t-1}} \\
& \text { TATA }=\frac{{\text { total } \text { accrual }_{t}}_{\text {sales }_{t}}}{{\text { total } \text { accrual }_{t-1}}_{\text {sales }_{t-1}}}
\end{aligned}
$$

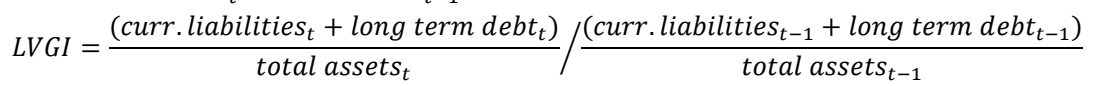

The limit value of the model is -2.22 , which indicates that if the M-score is less than the threshold value, the enterprise is unlikely to be a manipulator and vice versa.

3. With respect to the limitation of the Beneish model, the modified Jones model (Dechow et al., 1995) was used to confirm earnings manipulation. This model (Equation 3), based on linear regression, was applied, as it was proven by Kliestik et al. (2020a) that it brings the most relevant results in the Visegrad conditions.

$$
\begin{aligned}
& \frac{N D A_{i t}}{T A_{\mathrm{t}-1}}=\alpha_{0} \frac{1}{A_{\mathrm{it}-1}}+\alpha_{1} \frac{\Delta R E V_{i t}-\Delta R E C_{i t}}{A_{i t-1}}+\alpha_{2} \frac{P P E_{i t}}{A_{i t-1}}+\varepsilon_{i t} \\
& \left(T A_{\mathrm{t}-1}=N D A_{i t}+D A_{i t}\right)
\end{aligned}
$$

where

$\mathrm{NDA}_{\mathrm{it}} \quad$ nondiscretionary accrual in a year $\mathrm{t}$

$\mathrm{DA}_{\mathrm{it}}$ discretionary accrual in a year $\mathrm{t}$

$\mathrm{TA}_{\mathrm{t}-1} \quad$ total accrual in a year $\mathrm{t}$

$\mathrm{A}_{\mathrm{it}-1} \quad$ total assets in a year $\mathrm{t}-1$

$\triangle \mathrm{REV}_{\text {it }}$ annual change in revenues in a year $\mathrm{t}$ 
$\Delta \mathrm{REC}_{\mathrm{it}} \quad$ annual change in receivables in a year $\mathrm{t}$

$\mathrm{PPE}_{\mathrm{it}} \quad$ long-term tangible assets in a year

$\alpha_{0}, \alpha_{1}, \alpha_{2} \quad$ coefficients

$\varepsilon_{\text {it }} \quad$ prediction error

The modified Jones model used financial data from all enterprises as input variables. The model determines the non-discretionary accruals, which are calculated using the coefficients of the linear regression in the model. The discretionary accruals (providing the opportunity to manipulate earnings) are then computed as the difference between total accrual and nondiscretionary accrual for each enterprise in each year analyzed. It was assumed that there was no manipulation of earnings if the discretionary accruals were not different from zero. One sample $t$ test was run each year to determine whether the mean values of discretionary accruals were other than zero. If the mean value of discretionary accruals is different from zero, there is a high likelihood of manipulation.

4. Contingency tables were created to display the number of enterprises that were identically marked as manipulative or nonmanipulative by both the Beneish and modified Jones models.

5. The Pearson chi-square test was run at the significance level of 0.01 (to increase the amount of evidence and decrease the chances of false-positive results from $5 \%$ to $1 \%$ ) to find the level of dependence between an enterprise's financial health measured by the Z score and the likelihood of earnings manipulation, presented as the intersection of the Beneish and modified Jones models. A fundamental precondition of the correspondence analysis is the verification of the mutual dependence of the variables' categories. If mutual dependence is confirmed, the strength of the association is measured by Cramer's V, and the statistical significance of the contingency coefficient is verified.

6. Correspondence analysis is performed to examine the internal structure of contingency tables (in which categories of factors are similar to each other), as statistically significant dependence is determined between the analyzed factors. The practical result of the correspondence analysis is the visualization of the relations between rows and columns of the analyzed contingency tables. The points are projected in the multidimensional space, portraying rows and columns of the contingency table into the correspondence map, where the chi-square distance measure is used. The closer the points in the correspondence map, the more similar the categories and the stronger their mutual correspondence. The degree that characterizes the quality of the transportation of multidimensional points into a correspondence map is determined by the variability of multidimensional points. The variability is measured by the total inertia, which is calculated for row categories as (Equation 5):

$I^{2}=\sum p_{i+} d_{i}^{2}$

where $\mathrm{I}$ is the total inertia, $\mathrm{p}_{\mathrm{i}+}$ is the marginal relative frequency of row $\mathrm{i}$ and $\mathrm{d}_{\mathrm{i}}$ is the chi-square distance between row i’s profile (Kovacova et al., 2019; Durana et al., 2019a). Analogically, the same procedure is applied to determine column categories. 


\section{RESULTS AND DISCUSSION}

The results of the calculations of the M-score and discretionary accruals in the modified Jones model indicate the number of enterprises with earnings manipulation practices -0 is used to designate enterprises with no earnings manipulation, and 1 indicates enterprises where earnings management was detected. The intersection of manipulative and nonmanipulative enterprises calculated by both models for each period is summarized in Table 1. The results indicate that the volume of jointly identified manipulative and nonmanipulative enterprises exceeds the number of enterprises producing different results in the model. Importantly, there is a high number of enterprises that practice earnings management to present their financial results in the most positive way, thus maintaining their position in the market and remaining stable and competitive for creditors and investors. Trends in earnings manipulation cannot be identified, as the percentage of manipulative enterprises fluctuates - from $73.65 \%$ in 2017 to $58.63 \%$ in 2019 . This development is highly influenced by a country's economic, political and financial situation, as found by Kliestik et al. (2020b), Svabova et al. (2020), Sumiyana (2020) and the report of Schwab (2019), confirming these findings.

Tab. 1 - The intersection of Beneish and modified Jones models. Source: own research

\begin{tabular}{|c|c|c|c|c|c|}
\hline \multirow{2}{*}{\multicolumn{2}{|c|}{ Beneish model }} & \multicolumn{2}{|c|}{ Modified Jones model } & \multirow{2}{*}{$\begin{array}{l}\text { Detection } \\
\text { of earnings } \\
\text { management }(\%)\end{array}$} & \multirow{2}{*}{$\begin{array}{l}\text { No } \\
\text { manipulation } \\
(\%)\end{array}$} \\
\hline & & 0 & 1 & & \\
\hline \multirow{2}{*}{2019} & 0 & 236 & 3,951 & \multirow{2}{*}{58.63} & \multirow{2}{*}{2.13} \\
\hline & 1 & 407 & 6,511 & & \\
\hline \multirow{2}{*}{2018} & 0 & 859 & 3,453 & \multirow{2}{*}{48.21} & \multirow{2}{*}{7.74} \\
\hline & 1 & 1,439 & 5,354 & & \\
\hline \multirow{2}{*}{2017} & 0 & 205 & 2,239 & \multirow{2}{*}{73.65} & \multirow{2}{*}{1.85} \\
\hline & 1 & 482 & 8,179 & & \\
\hline
\end{tabular}

In terms of the number of enterprises with earnings manipulation, there were 3,156 enterprises that managed their earnings in each of the analyzed years (with just one enterprise that did not). The results indicate that the sector does not play a relevant role in earnings manipulation, as efforts to attract investors and stay competitive are important across the entire economic spectrum. These results are confirmed by the studies of Siekelova et al. (2019) and Virglerova et al. (2020). The next step of the analysis is to determine if there is a statistically significant dependence between the financial health of enterprises and the manipulation of earnings. The Pearson chi-square test was run at a significance level of 0.01 to verify the hypotheses (Table 2). 
Tab. 2 - Verification of the dependence between financial health and earnings management. Source: own research

\begin{tabular}{|l|l|l|l|l|l|}
\hline Year & $\begin{array}{l}\text { P-value of } \\
\text { Pearson chi- } \\
\text { square test }\end{array}$ & Decision & Cramer's V & $\begin{array}{l}\text { P-value of } \\
\text { Cramer's V }\end{array}$ & Decision \\
\hline 2019 & 0.000 & H1 & 0.060 & 0.000 & $\begin{array}{l}\text { Sig. weak } \\
\text { association }\end{array}$ \\
\hline 2018 & 0.000 & H1 & 0.073 & 0.000 & $\begin{array}{l}\text { Sig. weak } \\
\text { association }\end{array}$ \\
\hline 2017 & 0.000 & H1 & 0.046 & 0.000 & $\begin{array}{l}\text { Sig. weak } \\
\text { association }\end{array}$ \\
\hline
\end{tabular}

The results of the chi-square test show a weak association between the $\mathrm{Z}$ score and $\mathrm{M}$-score, which means that the manipulation of earnings is influenced by the financial stability of enterprises in the Visegrad countries. Thus, information on the financial health of enterprises may be a good indicator of manipulative behavior. Therefore, simple correspondence analysis was further used to show the relationship between the categories of both variables at the same time; mutual relationships between row (Table 3) and column categories (Table 4) were analyzed for each year. Table 3 depicts the values, which help evaluate how each row contributes to the dimension and how each dimension contributes to the rows.

Tab. 3 - Overview of rows in each analyzed period. Source: own research

\begin{tabular}{|c|c|c|c|c|c|c|c|c|c|}
\hline \multicolumn{10}{|c|}{ Overview Row Points } \\
\hline \multirow{3}{*}{ Altman_2019 } & \multirow{3}{*}{ Mass } & \multicolumn{2}{|c|}{$\begin{array}{l}\text { Score in Di- } \\
\text { mension }\end{array}$} & \multirow{3}{*}{ Inertia } & \multicolumn{5}{|c|}{ Contribution } \\
\hline & & \multirow[t]{2}{*}{1} & \multirow[t]{2}{*}{2} & & \multicolumn{2}{|c|}{$\begin{array}{l}\text { Of Point to } \\
\text { Inertia of } \\
\text { Dimension }\end{array}$} & \multicolumn{3}{|c|}{$\begin{array}{l}\text { Of Dimension to } \\
\text { Inertia of Point }\end{array}$} \\
\hline & & & & & 1 & 2 & 1 & 2 & Total \\
\hline gray zone & 0.257 & -0.089 & -0.199 & 0.000 & 0.024 & 0.719 & 0.538 & 0.462 & 1.000 \\
\hline distress & 0.137 & -0.665 & 0.121 & 0.005 & 0.721 & 0.142 & 0.994 & 0.006 & 1.000 \\
\hline healthy & 0.606 & 0.188 & 0.057 & 0.002 & 0.255 & 0.139 & 0.985 & 0.015 & 1.000 \\
\hline Active Total & 1.000 & & & 0.007 & 1.000 & 1.000 & & & \\
\hline \multicolumn{10}{|l|}{ Altman 2018} \\
\hline gray zone & 0.257 & 0.086 & 0.221 & 0.000 & 0.019 & 0.724 & 0.471 & 0.529 & 1.000 \\
\hline distress & 0.134 & 0.749 & -0.128 & 0.008 & 0.739 & 0.127 & 0.995 & 0.005 & 1.000 \\
\hline healthy & 0.609 & -0.201 & -0.065 & 0.003 & 0.242 & 0.149 & 0.983 & 0.017 & 1.000 \\
\hline Active Total & 1.000 & & & 0.011 & 1.000 & 1.000 & & & \\
\hline \multicolumn{10}{|l|}{ Altman 2017} \\
\hline gray zone & 0.258 & -0.083 & 0.199 & 0.000 & 0.028 & 0.714 & 0.433 & 0.567 & 1.000 \\
\hline distress & 0.131 & -0.588 & -0.128 & 0.003 & 0.720 & 0.149 & 0.989 & 0.011 & 1.000 \\
\hline
\end{tabular}




\begin{tabular}{|l|l|l|l|l|l|l|l|l|l|}
\hline healthy & 0.611 & 0.161 & -0.057 & 0.001 & 0.252 & 0.137 & 0.973 & 0.027 & 1.000 \\
\hline Active Total & 1.000 & & & 0.004 & 1.000 & 1.000 & & & \\
\hline
\end{tabular}

Tab. 4 - Overview of columns in each analyzed period. Source: own research

\begin{tabular}{|c|c|c|c|c|c|c|c|c|c|}
\hline \multicolumn{10}{|c|}{ Overview Column Points } \\
\hline \multirow{3}{*}{$\begin{array}{l}\text { Beneish Jones } \\
2019\end{array}$} & \multirow{3}{*}{ Mass } & \multicolumn{2}{|c|}{$\begin{array}{l}\text { Score in Di- } \\
\text { mension }\end{array}$} & \multirow{3}{*}{ Inertia } & \multicolumn{5}{|c|}{ Contribution } \\
\hline & & \multirow[t]{2}{*}{1} & \multirow[t]{2}{*}{2} & & \multicolumn{2}{|c|}{$\begin{array}{l}\text { Of Point to } \\
\text { Inertia of } \\
\text { Dimension }\end{array}$} & \multicolumn{3}{|c|}{$\begin{array}{l}\text { Of Dimension to } \\
\text { Inertia of Point }\end{array}$} \\
\hline & & & & & 1 & 2 & 1 & 2 & Total \\
\hline 0 & 0.392 & 0.326 & -0.063 & 0.004 & 0.497 & 0.110 & 0.994 & 0.006 & 1.000 \\
\hline manipulation & 0.586 & -0.241 & 0.014 & 0.003 & 0.405 & 0.009 & 0.999 & 0.001 & 1.000 \\
\hline $\begin{array}{l}\text { no } \\
\text { manipulation }\end{array}$ & 0.021 & 0.621 & 0.767 & 0.01 & 0.098 & 0.881 & 0.794 & 0.206 & 1.000 \\
\hline Active Total & 1.000 & & & 0.007 & 1.000 & 1.000 & & & \\
\hline \multicolumn{10}{|c|}{ Beneish Jones 2018} \\
\hline 0 & 0.441 & -0.244 & 0.109 & 0.003 & 0.258 & 0.302 & 0.967 & 0.033 & 1.000 \\
\hline manipulation & 0.482 & 0.317 & -0.038 & 0.005 & 0.478 & 0.040 & 0.998 & 0.002 & 1.000 \\
\hline $\begin{array}{l}\text { no } \\
\text { manipulation }\end{array}$ & 0.077 & -0.590 & -0.384 & 0.003 & 0.264 & 0.685 & 0.933 & 0.067 & 1.000 \\
\hline Active Total & 1.000 & & & 0.011 & 1.000 & 1.000 & & & \\
\hline \multicolumn{10}{|c|}{ Beneish Jones 2017} \\
\hline 0 & 0.245 & 0.372 & 0.112 & 0.002 & 0.539 & 0.216 & 0.980 & 0.020 & 1.000 \\
\hline manipulation & 0.737 & -0.145 & -0.018 & 0.001 & 0.247 & 0.017 & 0.996 & 0.004 & 1.000 \\
\hline $\begin{array}{l}\text { no } \\
\text { manipulation }\end{array}$ & 0.018 & 0.854 & -0.772 & 0.001 & 0.214 & 0.767 & 0.843 & 0.157 & 1.000 \\
\hline Active Total & 1.000 & & & 0.004 & 1.000 & 1.000 & & & \\
\hline
\end{tabular}

The mass value in individual years presents the proportion of each row to the total number of enterprises $(11,105)$. The scores in dimension portray the scores of rows in the intended dimensions 1 or 2 , and they are representative of dimensional distance (used in the final correspondence map). The column with the values of inertia shows the amount of variance each row accounts for in the total inertia value. The contribution of the point of inertia of dimension (i.e., of dimension of inertia to point) explains the role of each row in the dimension (and vice versa). The most important results are found in the Total column, representing the sum of each dimension's role in the row and the proportion of row points on total inertia. The results of the overview column points (Table 4) can be clarified in the same manner. The results prove that in both cases (rows and column points), the two-dimensional correspondence map adequately reflects the analyzed categories, as the values of the contributions (Total column) equal one in all cases. 
The results of the correspondence analysis provide factor scores for both the row and column points of the contingency table. The output is an individual correspondent map for each row ( $\mathrm{Z}$ score) and column profile (earnings management practices). The overlay of both corresponding maps illustrates the final symmetric correspondence map in each analyzed year. The outputs of the correspondence analysis reveal very interesting results, and the relationship between the financial status of enterprises in the Visegrad countries and their earnings management practice becomes evident. Two groups can be identified. The research shows that earnings manipulation is common among financially distressed businesses and those in the gray zone (as defined by Altman's Z score), where it is impossible to predict the financial future of the enterprise. In both cases, the incentive to improve financial reports is evident, as enterprises need to present their financial results in the best possible light to maintain their competitive position in the market, access to loans, and credibility for investors and creditors. The analysis of the financial health of business entities and their approach toward earnings management by different statistical methods proves that there is a statistically significant dependence between the financial health of enterprises and the manipulation of their earnings, with emphasis on some specific categories that are mutually associated. Several studies bolster the findings of the robust analysis performed in the context of the conditions of the Visegrad countries. First, it is important to note that the use of two forensic accounting tools - the Beneish M s-core and the Altman Z score - is recommended for the effective detection of earnings manipulation by business entities (Bhavani \& Amponsah, 2017). Previous publications indicate that the financial situation of an enterprise may be more accurately determined when at least two models are used simultaneously. MacCarthy (2017) even states that the Altman Z score and Beneish M-model should be used together as an integral part of every audit. Jones \& Belkaoui (2010) emphasize that earnings are often the subject of systematic management while operating cash flows are more difficult to manipulate as they do not contain accruals or deferrals of any kind.

An increase in net accruals is a possible means of earnings manipulation (Jones, 1991). This phenomenon frequently occurs among distressed businesses (Jones, 2011; Suhaily et al., 2013). The situation is further complicated by the fact that profit-based indicators are often considered the most significant predictors of distress (Altman, 1968; Shumway, 2001; Vrbka et al., 2019). In the context of predicting bankruptcy, the situation is even more complicated, as distressed companies have a high propensity to engage in earnings management (Jones, 2016). Suhaily et al. (2013) confirm that financial distress is significantly and positively related to fraudulent financial reporting. The research on discretionary accruals of enterprises threatened by bankruptcy confirms that enterprises filing for bankruptcy use earnings management excessively (Leach \& Newsom, 2007). Charitou et al. (2007) declare that enterprises employ earnings manipulation to avoid violations of debt covenants in times of financial distress, allowing greater access to leverage. The study by Campa et al. (2015) was focused on the prebankruptcy conditions of small and medium-sized enterprises and their impact on earning management tools. The main conclusion of their study was that the level of financial distress affects the way in which earnings are manipulated. The more serious the prebankruptcy distress, the greater the attempt to manipulate earnings through real transactions (and less through discretionary accruals). Investors should, therefore, be more skeptical of information on earnings, especially when a 
firm is in financial distress. However, completely different results were presented in the study of Agustia et al. (2020), who claim that there is no relation between bankruptcy risk and earnings management behavior when enterprises implement one of two business strategies involving cost leadership of differentiation, thereby mitigating bankruptcy risk. However, bankruptcy risk changes throughout the corporate life cycle (Khan \& Thu, 2019), and earnings manipulation may be more significant during the introduction and decline phases (Hussain et al., 2020).

\section{CONCLUSION}

The global economic recession caused by the COVID-19 pandemic last year highlighted an unexpected risk to the world (Shaeres et al., 2020; Lazaroiu \& Adams, 2020). The economic disorder that affected every country in the world poses the threat of financial distress and fraud. However, as stated by Avianatara (2021), specific prediction and detection models may be used as a pre-elementary assessment tool to facilitate decisions on whether to put trust in certain companies.

This research demonstrates the mutual dependence between corporate financial health and earnings management and confirms that an enterprise on the verge of bankruptcy (or in the gray zone) may be engaged in the manipulation of earnings to maintain competitiveness and present its financial position in the most positive light. The results of the categorical data analysis supported by the output of the correspondence analysis revealed a statistically significant dependence between an enterprise's financial health and the manipulation of earnings. Moreover, financial distress may be associated with manipulative behavior, while enterprises in which earnings manipulation cannot be clearly detected are assumed to be financially healthy. The results of the paper provide important and useful information for investors, creditors, auditors, and regulators, as the effect of earnings management on financial health is essential to assess the financial capability, creditworthiness, and truthfulness of enterprises' financial reports. However, this research should be supported by the relevant state authorities through the introduction of tools that may help identify earnings management practices and protect market subjects from the financial risks they face from the reporting of spurious financial information.

Despite the robust dataset of business entities that was analyzed, there are some limitations to the research. The research was conducted using the information on the Visegrad enterprises from the 4-year period. However, panel data and longitudinal data should be applied to extend the measurement over time, which would enrich the research results in several respects. It would also be interesting to analyze the impact of ownership, company size, lifecycle and length of operation on overall financial stability and earning management practices, which will be the impetus of future research.

Acknowledgements: This research was financially supported by the Slovak Research and Development Agency - Grant NO. APVV-17-0546: Variant Comprehensive Model of Earnings Management in Conditions of the Slovak Republic as an Essential Instrument of Market Uncertainty Reduction. 


\section{References}

1. Agustia, D., Muhammad, N. P. A., \& Permatasari, Y. (2020). Earnings management, business strategy, and bankruptcy risk: Evidence from Indonesia. Heliyon, 6 (2), e03317. https://doi.org/10.1016/j.heliyon.2020.e03317

2. Ahmadpour, A., \& Shahsavari, M. (2016). Earnings management and the effect of earnings quality in relation to bankruptcy level (Firms listed at the Tehran stock exchange). Iranian Journal of Management Studies, 9 (1), 77-99. https://doi.org/10.22059/IJMS.2016.55036

3. Al-Delawi, A. S., \& Ramo, W. M. (2020). The impact of accounting information systems on performance management. Polish Journal of Management Studies, 21 (2), 36-48. http://dx.doi.org/ 10.17512/pjms.2020.21.2.03

4. Altman, E.I. (1968). Financial ratios, discriminant analysis and the prediction of corporate bankruptcy. The Journal of Finance, 23 (4), 589-609. https://doi.org/10.1111/j.1540-6261.1968. tb00843.x

5. Argawal, K., \& Chatterjee, C. (2015). Earnings management and financial distress: Evidence from India. Global Business Review, 16 (5), 140-154. https://doi.org/10.1177/0972150915601928

6. Aviantara, R. (2021). Scoring the financial distress and the financial statement fraud of Garuda Indonesia with DDCC as the financial solutions. Journal of Modelling in Management, Early Access, January 2021. https://doi.org/10.1108/JM2-01-2020-0017

7. Balasubramnian, B., Pavlia, A. A., \& Patro, D. K. (2019). Can the book-to-market ratio signal banks' earnings and default risk? Evidence around the Great Recession. Journal of Financial Services Research, 56 (2), 119-143. https://doi.org/10.1007/s10693-018-0299-4

8. Belas, J., Amoah, J., Petrakova, Z., Kliuchnikava, Y., \& Bilan, Y. (2020b). Selected factors of SMEs management in the service sector. Journal of Tourism and Services, 21 (11), 129-146. http://dx.doi.org/10.29036/jots.v11i21.215

9. Belas, J., Gavurova, B., Cepel, M., \& Kubak, M. (2020a). Evaluation of the economic potential of business environment by comparing sector differences: Perspective of SMEs in the Czech Republic and Slovakia. Oeconomia Copernicana, 11 (1), 135-159. https://doi.org/10.24136/ oc. 2020.006

10. Beneish, M. D. (1999). The detection of earnings manipulation. Financial Analysts Journal, 55 (5), 24-36. https://doi.org/10.2469/faj.v55.n5.2296

11. Beneish, M. D., Press, E., \& Vargus, M. E. (2012). Insider trading and earnings management in distressed firms. Contemporary Accounting Research, 29 (1), 191-220.

https://doi.org/10.1111/j.1911-3846.2011.01084.x

12. Bhavani, G., \& Amponsah, C. T. (2017). M-score and Z-score for detection of accounting fraud. Accountancy Business and the Public Interest, 1, 68-86.

13. Campa, D., \& Camacho-Minano, M. (2015). The impact of SME's pre-bankruptcy financial distress on earnings management tools. International Review of Financial Analysis, 42, 222-234. https://doi.org/10.1016/j.irfa.2015.07.004

14. Chang, H. Y., Liang, L. H., \& Yu, H. F. (2019). Market power, competition and earnings management: accrual-based activities. Journal of Financial Economic Policy, 11 (3), 368-384. https://doi.org/10.1108/JFEP-08-2018-0108 
15. Charitou, A., Lambertides, N., \& Trigeorgis, L. (2007). Earnings behaviour of financially distressed firms: the role of institutional ownership. Abacus, 43 (3), 271-296. https://doi.org/10.1111/j.1467-6281.2007.00230.x

16. Chen, Y., Chen, C. H., \& Huang, S. L. (2010). An appraisal of financially distressed companies' earnings management: Evidence from listed companies in China. Pacific Accounting Review, 22 (1), 22-41. https://doi.org/10.1108/01140581011034209

17. Chen, A., Chu, H., Hung, P., \& Cheng, M. S. (2020). Financial risk and acquirers's stockholder wealth in mergers and acquisitions. North American Journal of Economics and Finance, 54, 100815. https://doi.org/10.1016/j.najef.2018.07.016

18. Cho, S., Fu, L., \& Yu, Y. (2012). New risk analysis tools with accounting changes: adjusted Z-score. Journal of Credit Risk, 8 (1), 89-108. https://doi.org/10.21314/JCR.2012.137

19. Chou, P. L., Chang, Y. M., \& Li, S. J. (2012). The study of earnings management, corporate information disclosure, and financial distress: Evidence from Taiwan. Journal of Information \& Optimization Sciences, 33 (1), 77-87. https://doi.org/10.1080/02522667.2012.10700135

20. Datta, S., Iskandar-Datta, M., \& Singh, V. (2013). Product market power, industry structure, and corporate earnings management. Journal of Banking and Finance, 37 (8), 3273-3285. https://doi.org/10.1016/j.jbankfin.2013.03.012

21. Deakin, E. B. (1972). A Discriminant Analysis of Predictors of Business Failure. Journal of Accounting Research, 10 (1), 167-179. https://doi.org/10.2307/2490225

22. Dechow, P. M., Sloan, R. G., \& Sweeney, A. P. (1995). Detecting earnings management. The Accounting Review, 70 (2), 193-225.

23. Durana, P., Kral, P., Stehel, V., Lazaroiu, G., \& Sroka, W. (2019). Quality Culture of Manufacturing Enterprises: A Possible Way to Adaptation to Industry 4.0. Social Sciences, 8 (4), 124. https://doi.org/10.3390/socsci8040124

24. Durana, P., Zauskova, A., Vagner, L., \& Zadnanova, S. (2020). Earnings drivers of Slovak manufacturers: Efficiency assessment of innovation management. Applied Sciences, 10 (12), 4251. https://doi.org/10.3390/app10124251

25. El Diri, M. (2020). Earning management, managerial ability, and the Role of Competition. Leeds: University of Leeds. https://10.13140/RG.2.2.31478.42566

26. Fialova, V., \& Folvarcna, A. (2020). Default prediction using neural networks for enterprises from the post-soviet country. Ekonomicko-manazerske spektrum, 14 (1), 43-51. http://dx.doi.org/10.26552/ems.2020.1.43-51

27. Gavurova, B., Ivankova, V., Rigelsky, M., \& Privarova, M. (2020). Relations between tourism spending and global competitiveness - an empirical study in developed OECD countries. Journal of Tourism and Services, 21 (11), 38-54. https://doi.org/10.29036/jotc.v11i21.175

28. Gilson, S. C. (1989). Management turnover and financial distress. Journal of Financial Economics, 25, 241-262. https://doi.org/10.1016/0304-405X(89)90083-4

29. Gottardo, P., \& Moisello, A.M. (2019. Capital structure, earnings management, and risk of financial distress: A comparative analysis of family and non-family firms. Verlag Berlin: Springer. 
30. Grofcikova, J. (2020). Impact of selected determinants of corporate governance on financial performance of companies. Ekonomicko-manazerske spektrum, 14 (2), 12-23.

https://doi.org/10.26552/ems.2020.2.12-23.

31. Habib, A., Bhuiyan, M. B. U., \& Islam, A. (2013). Financial distress, earnings management and market pricing of accruals during the global financial crisis. Managerial Finance, 39 (2), 155-180. https://doi.org/10.1108/03074351311294007

32. Hakami, T. A., Rajmat, M. M., Yaacob, M. H., \& Saleh, N. M. (2020). Fraud detection gap between auditor and fraud detection models: Evidence from Gulf Cooperation Council. Asian Journal of Accounting and Governance, 13, 1-13. https://doi.org/10.17576/AJAG-2020-13-01

33. Hoang, T. C., \& Joseph, D. M. (2019). The effect of new corporate accounting regime on earnings management: Evidence from Vietnam. Journal of International Studies, 12 (1), 93-104. http://dx.doi.org/10.14254/2071-8330.2019/12-1/6

34. Hussain, A., Akbar, M., Kaleem Khan, M., Akbar, A., Panait, M., \& Catalin Voica, M. (2020). When does earnings management matter? Evidence across the corporate life cycle for non-financial Chinese listed companies. Journal of Risk and Financial Management, 13 (12), 313. https://doi.org/10.3390/jrfm13120313

35. Jacoby, G., Li, J., \& Liu, M. (2019). Financial distress, political affiliation and earnings management: The case of politically affiliated private firms. European Journal of Finance, 26 (6), 508-523. https://doi.org/10.1080/1351847X.2016.1233126

36. Jones, J. J. (1991). Earnings management during import relief investigations. Journal of Accounting Research, 29 (2), 193-228. https://doi.org/10.2307/2491047

37. Jones, S. (2011). Does the capitalization of intangible assets increase the predictability of corporate failure? Accounting Horizons, 25, 41-70. https://doi.org/10.2308/acch.2011.25.1.41

38. Jones, S. (2016). A cash flow-based model of corporate bankruptcy in Australia. Journal of Applied Management Accounting Research, 3 (2), 21-35.

39. Jones S., \& Belkaoui, R. H. (2010). Financial Accounting Theory. Sydney: Cengage.

40. Khalid, M., Abbas, Q., \& Nazir, M. S. (2020). Efficiently monitoring the ship of financially distressed companies sinking in Iron law of earnings management: Evidence from Pakistan. Cogent Economics \& Finance, 8 (1), 1838685. https://doi.org/10.1080/23322039.2020.1838685

41. Khan, K. A., Dankiewicz, R., Kliuchnikava, Y., \& Olah, J. (2020). How do entrepreneurs feel bankruptcy? International Journal of Entrepreneurial Knowledge, 8 (1), 89-101.

http://dx.doi.org/10.37335/ijek.v8il.103

42. Khanh, M. T. H, \& Thu, P. A. 2019. The effect of financial leverage on real and accrual-based earnings management in Vietnamese firms. Economics and Sociology, 12 (4), 299-312. http://dx.doi.org/10.14254/2071-789X.2019/12-4/18

43. Khuong, N. V., Liem, N. T., \& Minh, M. T. H. (2020). Earnings management and cash holdings: Evidence from energy firms in Vietnam. Journal of International Studies, 13 (1), 247-261. http://dx.doi.org/10.14254/2071-8330.2020/13-1/16

44. Kjærland, F., Haugdal, A. T., Sondergaard, A., \& Vagslid, A. (2020). Corporate governance and earnings management in a Nordic perspective: evidence from the Oslo stock exchange. Journal of Risk and Financial Management, 13 (11), 256, https://doi.org/10.3390/jrfm13110256 
45. Kliestik, T., Belas, J., Valaskova, K., Nica, E., \& Durana, P. (2020a). Earnings management in V4 countries: The evidence of earnings smoothing and inflating. Economic ResearchEkonomska Istrazivanja, early access, October 2020.

https://doi.org/10.1080/1331677X.2020.1831944

46. Kliestik, T., Valaskova, K., Nica, E., Kovacova, M., \& Lazaroiu, G. (2020b). Advanced methods of earnings management: Monotonic trends and change points under the spotlight in the Visegrad countries. Oeconomia Copernicana, 11 (2), 371-400.

https://doi.org/10.24136/oc.2020.016

47. Kordestani, G. R., \& Mohammadi, M. R. (2016). A study of the relationship between product market competition and earnings management. Procedia Economics and Finance, 36, 266-273. https://doi.org/10.1016/S2212-5671(16)30037-5

48. Kovacova, M., Kliestik, T., Valaskova, K., Durana, P., \& Juhaszova, Z. (2019). A systematic review of variables applied in bankruptcy prediction models of Visegrad group countries. Oeconomia Copernicana, 10 (4), 743-772. https://doi.org/10.24136/oc.2019.034

49. Kramolis, J., \& Dobes, K. (2020). Debt as a financial risk factor in SMEs in the Czech Republic. Equilibrium. Quarterly Journal of Economics and Economic Policy, 15 (1), 87-105. https://doi.org/10.24136/eq.2020.005

50. Laksmana, I., \& Yang, Y. (2015). Product market competition and corporate investment decisions. Review of Accounting and Finance, 14 (2), 128-148.

https://doi.org/10.1108/RAF-11-2013-0123

51. Lazaroiu, G., \& Adams, C. (2020). Viral Panic and Contagious Fear in Scary Times: The Proliferation of COVID-19 Misinformation and Fake News. Analysis and Metaphysics, 19, 80-86. https://doi.org/10.22381/AM1920209

52. Leach, R., \& Newsom, P. (2007). Do firms manage their earnings prior to filing for bankruptcy? Academy of Accounting and Financial Studies Journal, 11 (3), 125-137.

53. Li, Y., Li, X., Xiang, E., \& Djajadikerta, H. G. (2020). Financial distress, internal control, and earnings management: Evidence from China. Journal of Contemporary Accounting \& Economics, 16 (3), 100210. https://doi.org/10.1016/j.jcae.2020.100210

54. Lin, H. W., Lo, H. C., \& Wu, R. S. (2016). Modeling default prediction with earnings management. Pacific-Basin Finance Journal, 40 (SI), 306-322.

https://doi.org/10.1016/j.pacfin.2016.01.005

55. Lyons, N., \& Lazaroiu, G. (2020). Addressing the COVID-19 Crisis by Harnessing the Internet of Things Sensors and Machine Learning Algorithms in Data-driven Smart Sustainable Cities. Geopolitics, History, and International Relations, 12 (2), 65-71. https://doi.org/10.22381/GHIR12220209

56. MacCarthy, J. (2017). Using Altman Z-score and Beneish M-score models to detect financial fraud and corporate failure: A case study of Enron Corporation. International Journal of Finance and Accounting, 6 (6), 159-166. http://doi.org/10.5923/j.ijfa.20170606.01

57. Malik, A., Din, S.U., Shafi, K., Butt, B. Z., \& Aziz, H. (2019). Earnings management and the likelihood of financial distress in banks evidence from Pakistani commercial banks. Public Finance Quarterly-Hungary, 64 (2), 208-221. 
58. Markarian, G. \& Santalo, J. (2014). Product market competition, information and earnings management. Journal of Business Finance and Accounting, 41 (3), 572-599.

https://doi.org/10.1111/jbfa.12064

59. Pustylnick, I. (2015). Use of Z-Score in Detection of Revenue Manipulations. Proceedings of the 21st International Conference on Economics and Management. 21st International Conference on Economics and Management, Brno, Czech Republic.

http://dx.doi.org/10.2139/ssrn.2577473

60. Pustylnick, I. (2017). Comparison of liquidity based and financial performance based indicators in financial analysis. Oeconomia Copernicana, 8 (1), 83-97.

https://doi.org/10.24136/oc.v8i1.6

61. Razali, W. A., \& Arshad, R. (2014). Disclosure of corporate governance structure and the likelihood of fraudulent financial reporting. Procedia Social and Behavioral Sciences, 145, 243-253. https://doi.org/10.1016/j.sbspro.2014.06.032

62. Sadiq M., Pantamee A. A., Mohamad S., Aldeehani M. T., \& Ady S. U. (2020). Corporate governance and earnings management: Evidence from listed non-financial firms. Polish Journal of Management Studies, 22 (2), 456-469. https://doi.org/10.17512/pjms.2020.22.2.30

63. Savova, K. (2021). Variable application of accounting standards - current aspects. Ekonomickomanazerske spektrum, 15 (1), 111-122. https:// dx.doi.org/10.26552/ems.2021.1.111-122.

64. Sayidah, N., Assagaf, A., \& Faiz, Z. (2020). Does earnings management affect financial distress? Evidence from state-owned enterprises in Indonesia. Cogent Business \& Management, 17 (1), 1832826. https://doi.org/10.1080/23311975.2020.1832826

65. Schwab, K. (2019). The global competitiveness report 2019. Switzerland: World Economic Forum.

66. Siekelova, A., Androniceanu, A., Durana, P., \& Frajtova Michalikova, K. (2020). Earnings Management (EM), initiatives and company size: an empirical study. Acta Polytecbnica Hungarica, 17 (9), 41-56.

67. Siekelova, A., Kovacova, M., Adamko, P., \& Stehel, V. (2019). Profit management as an instrument for SMEs developing: The case for Slovakia. Marketing and Management of Innovations, 3, 285-296. http://doi.org/10.21272/mmi.2019.3-22

68. Sheares, G., Miklencicova, R., \& Grupac, M. (2020). The Viral Power of Fake News: Subjective Social Insecurity, COVID-19 Damaging Misinformation, and Baseless Conspiracy Theories. Linguistic and Philosophical Investigations, 19, 121-127.

http://doi.org/10.22381/LPI1920209

69. Shumway, T. (2001). Forecasting Bankruptcy More Accurately: A Simple Hazard Model. Journal of Business, 74 (1), 101-24. https://doi.org/10.1086/209665

70. Suhaily, H., Rashidah, A. R., \& Mahenthiran S. (2013). Management Motive, Weak Governance, Earnings Management, and Fraudulent Financial Reporting: Malaysian Evidence. Journal of International Accounting Research, 12 (1), 1-27. https://doi.org/10.2308/jiar-50353

71. Sumiyana, S. (2020). Different characteristics of the aggregate of accounting earnings between developed and developing countries: Evidence for predicting future GDP. Journal of International Studies, 13 (1), 58-80. http://dx.doi.org/10.14254/2071-8330.2020/13-1/4 
72. Susanto, Y. K., Pirzada, K., \& Adrianne, S. (2019). Is tax aggressiveness an indicator of earnings management? Polish Journal of Management Studies, 20 (2), 516-527.

http://dx.doi.org/10.17512/pjms.2019.20.2.43

73. Svabova, L., Kramarova, K., Chutka, J., \& Strakova, L. (2020). Detecting earnings manipulation and fraudulent financial reporting in Slovakia. Oeconomia Copernicana, 11 (3), 485-508. https://doi.org/10.24136/oc.2020.020

74. Tbalvandani, M. R., \& Nashtei, R.A. (2017). Investigating the earnings quality characteristics and earnings management type in bankrupt and distressed companies (Case study: companies listed on Tehran Stock Exchange). Helix, 7 (2), 907-915.

75. Virglerova, Z., Conte, F., Amoah, J., \& Massaro, M. R. (2020). The perception of legal risk and its impact on the business of SMEs. International Journal of Entrepreneurial Knowledge, 8 (2), 1-13. http://dx.doi.org/10.37335/ijek.v8i2.115

76. Vrbka, J., Nica, E., \& Podhorska, I. (2019). The application of Kohonen networks for the identification of leaders in the trade sector in Czechia. Equilibrium. Quarterly Journal of Economics and Economic Policy, 14 (4), 739-761. https://doi.org/10.24136/eq.2019.034

77. Xu, C., Zhang, H., Hao, J., \& Guo, L. (2021). Real earnings management in bankrupt firms. Journal of Corporate Accounting and Finance, early access, January 2021. https://doi.org/10.1002/jcaf.22483

\section{Contact information}

assoc. prof. Katarina Valaskova, Ph.D.

University of Zilina, Faculty of Operation and

Economics of Transport and Communications,

Department of Economics, Univerzitna 1

Slovakia

E-mail:katarina.valaskova@fpedas.uniza.sk. ORCID: 0000-0003-4223-7519

Ane-Mari Androniceanu

The Bucharest University of Economic Studies

Doctoral School of Management, Bucharest

Romania

E-mail: ane.androniceanu.drd@gmail.com

ORCID: 0000-0002-1441-4496

Ing. Katarina Zvarikova, PhD.

University of Zilina, Faculty of Operation and Economics of Transport and Communications, Department of Economics, Univerzitna 1

Slovakia

E-mail:katarina.zvarikova@,fpedas.uniza.sk

ORCID: 0000-0001-5278-9275 prof. Dr. Judit Olah, Ph.D.

Faculty of Economics and Business, University of Debrecen, 4032 Debrecen, Hungary TR ADE

Research Entity, North-West University, Potchefstroom 2351, South Africa

Hungary/South Africa

E-mail:olah.judit@econ.unideb.bu

ORCID: 0000-0003-2247-1711 